\title{
Anticipated decrease in surgeons: does orthopedic internship affect medical students career choice?
}

\author{
Cerrahlarda beklenen azalma: ortopedi stajı tıp öğrencilerinin kariyer \\ seçimini etkiler mi?
}

\author{
๑İ̉brahim Deniz Canbeyli, @Meriç Çırpar \\ Kirikkale University, School of Medicine, Department of Orthopedics and Traumatology, Kirikkale, Turkey
}

Cite this article as/Bu makaleye atıf için: Canbeyli İD, Çırpar M. Anticipated decrease in surgeons: does orthopedic internship affect medical students career choice? J Health Sci Med 2020; 3(4): 395-402.

\begin{abstract}
Aim: The aim of this study is to determine medical students' career choices and to identify the effect of both demographic factors and the orthopedics residency education program on medical students' career choices.

Material and Method: This study was performed on a total of 154 medical students (92 females and 62 males; mean age 23.7 \pm 2.8 ) who attended Orthopedic internship program between 2018 and 2019 academic years. The students were subjected to a questionnaire twice on the first and last days of their internship program, which investigated distribution of selection of final year medical students' career choices and factors that may play role on this selection.

Results: Eighty-three (53.9\%) students had changed their preferences and 72 (46.8\%) had changed the order of preferences after Orthopedic internship program. The increase in the number of students who chose Orthopedics $(p<0.001)$ and who placed Orthopedics in first order in their list of preferences $(\mathrm{p}=0.039)$ was statistically significant after the Orthopedic internship program. There was no significant difference between the female and male students in terms of placing surgical branches first in their list of preferences before $(\mathrm{p}=0.955)$ and after Orthopedic internship program ( $\mathrm{p}=0.182)$. It was found that male students chose Orthopedics significantly more than females both before $(\mathrm{p}<0.001)$ and after $(\mathrm{p}<0.001)$ the internship.

Conclusion: We demonstrated that early and active recruitment in surgery and operating theatre with positive support of faculty, residents and even operating room staff may increase interest in orthopedic surgery both for male and female medical students.
\end{abstract}

Keywords: Career choice, medical education, undergraduate, orthopedic residency, surgical residency

ÖZ

Amaç: Bu çalışmanın amacı tıp öğrencilerinin kariyer seçimlerini ve demografik faktörlerin ve ortopedi uzmanlık eğitim programının tıp öğrencilerinin kariyer seçimleri üzerindeki etkisini belirlemektir.

Gereç ve Yöntem: Bu çalışma, 2018-2019 akademik yılları arasında Ortopedi stajına katılan toplam 154 tıp öğrencisi (92 kadın ve 62 erkek;

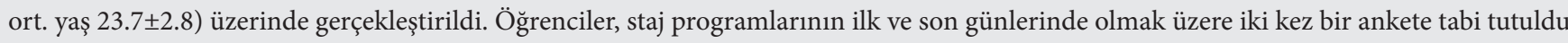
ve son sınıf tıp öğrencilerinin kariyer seçimi tercihleri ve bu seçimde rol oynayabilecek faktörler incelenmiştir.

Bulgular: Seksen üç $(\% 53,9)$ öğrenci Ortopedi stajından sonra tercihini ve 72 öğrenci $(\% 46,8)$ tercih sırasını değiştirmiştir. Ortopedi stajından sonra ortopedi tercih eden $(\mathrm{p}<0.001)$ ve ortopedi branşını tercih listesinde birinci sıraya yerleştiren $(\mathrm{p}=0.039)$ öğrenci sayısındaki artış istatistiksel olarak anlamlı bulunmuştur. Kız ve erkek öğrenciler arasında, ortopedi stajından önce ( $\mathrm{p}=0.955)$ ve sonra $(\mathrm{p}=0.182)$ cerrahi branşları tercih listesinde ilk sıraya koyma açısından anlamlı bir fark bulunmamıştır. Erkek öğrencilerin ortopedi branşını hem staj öncesi $(\mathrm{p}<0.001)$ hem de staj sonrasında $(\mathrm{p}<0.001)$ kız öğrencilerden anlamlı olarak daha fazla tercih ettikleri görülmüştür.

Sonuçlar: Öğretim üyeleri, araştırma görevlileri ve hatta ameliyathane personelinin olumlu desteği ile öğrencilerin ameliyatlara ve ameliyathaneye erken dönemde ve aktif olarak katılımlarının sağlanması hem erkek hem de kız tıp öğrencilerinin ortopedi branşına olan ilgisini artırabilir.

Anahtar Kelimeler: Kariyer seçimi, tıp eğitimi, lisans eğitimi, ortopedi asistanlığı, cerrahi branş asistanlığı 


\section{INTRODUCTION}

The number of specialists in each branch of medicine has a direct effect on the running of high-quality public healthcare services as well as on the continuance of medical education. However, some studies have reported a decrease in medical students'interest in surgical specialties $(1,2)$. Various factors have been found to affect medical students' career choices such as the individual characteristics, $(3,4)$ anticipation of a high income, (5) prestige, the education content, (6) and experiences at medical school, $(7,8)$ the desire for a controllable lifestyle, $(9,10)$ flexibility of working management, $(5,11)$ career features, (1) and sex (12). One branch of surgery, namely, Orthopedics and Traumatology (hereafter referred to as orthopedics) has also experienced a decrease in medical studentsinterest. In contrast, the number of patients seeking medical attention for musculoskeletal disease is high, (13) and has been reported to involve $20 \%$ of patients in primary care and emergency presentations $(14,15)$. To address the discrepancy between the need for healthcare and the number of medical professionals in this branch, the number of orthopedic surgeons should be increased to a sustainable level, and factors affecting medical career choices need to be clarified. Understanding the potential effects of the content of education, medical school experience, and other specific factors involved in selecting an orthopedics residency education may help program directors to guide students more effectively in selecting this internship. This study is a pioneering study that investigated the factors affected the specialty choice of medical students and if their preferences changed after the orthopedic internship.

In this study, we aimed to determine medical students career choice and to identify the effect of both demographic factors and the orthopedics education program on medical students' career choices.

\section{MATERIAL AND METHOD}

The study was approved by the local Ethics Committee (Date: 11.07.2018, Approval no. 2018.10.16) and performed in the skill practice laboratory of the Department of Orthopedics and Traumatology at Kırıkkale University School of Medicine. All reported research involving "Human beings" conducted in accordance with the principles set forth in the Helsinki Declaration 2008. This cross sectional study involve 154 final 5th-year medical faculty students (women, $\mathrm{n}=92$ [59.7\%]; men, $\mathrm{n}=62$ [40.3\%]; mean age, $23.7 \pm 2.8$ [range, 22-53] years) from the 2018-2019 academic year who had undergone an orthopedics internship program (OIP), at a university in Anatolia, Turkey. All the students who attend to OIP and volunteer for completing the questionnaire were included in the study. As a result of a post-hoc power analysis undertaken through, calculating a type 1 (alpha) error level at 0.05 , the power of the study was found to be $99 \%$ with 154 students. A theoretical and practical OIP is undertaken during the 5th year of medical school over 3 weeks for all students. In the orthopedic internship program, students take active recruitment in an orthopedic outpatient clinic, patients'room, and operation room under faculty, residents, and OR staff support. Students were requested to complete the previously described questionnaire, $(16,17)$ in which the sub-branches of medicine were divided into pre-clinical, non-surgical, and surgical categories to simplify statistical analyses and to accurately evaluate the preferences of specialties in Turkey. The students completed the questionnaire twice, once on the first day and again on the last day of their OIP. We investigated the distribution of final-year medical students' career choices and the factors that may have played a role in their selection process (Figure 1a, 1b). Data collected from final-year medical students who completed the questionnaire included demographic characteristics and the students'interest in each of the pre-clinical, non-surgical, and surgical subspecialties during their OIP in 2018-2019 academic year. Students who declined to volunteer for this study and those who did not complete the questionnaire were excluded (all students participated in the study and completed the

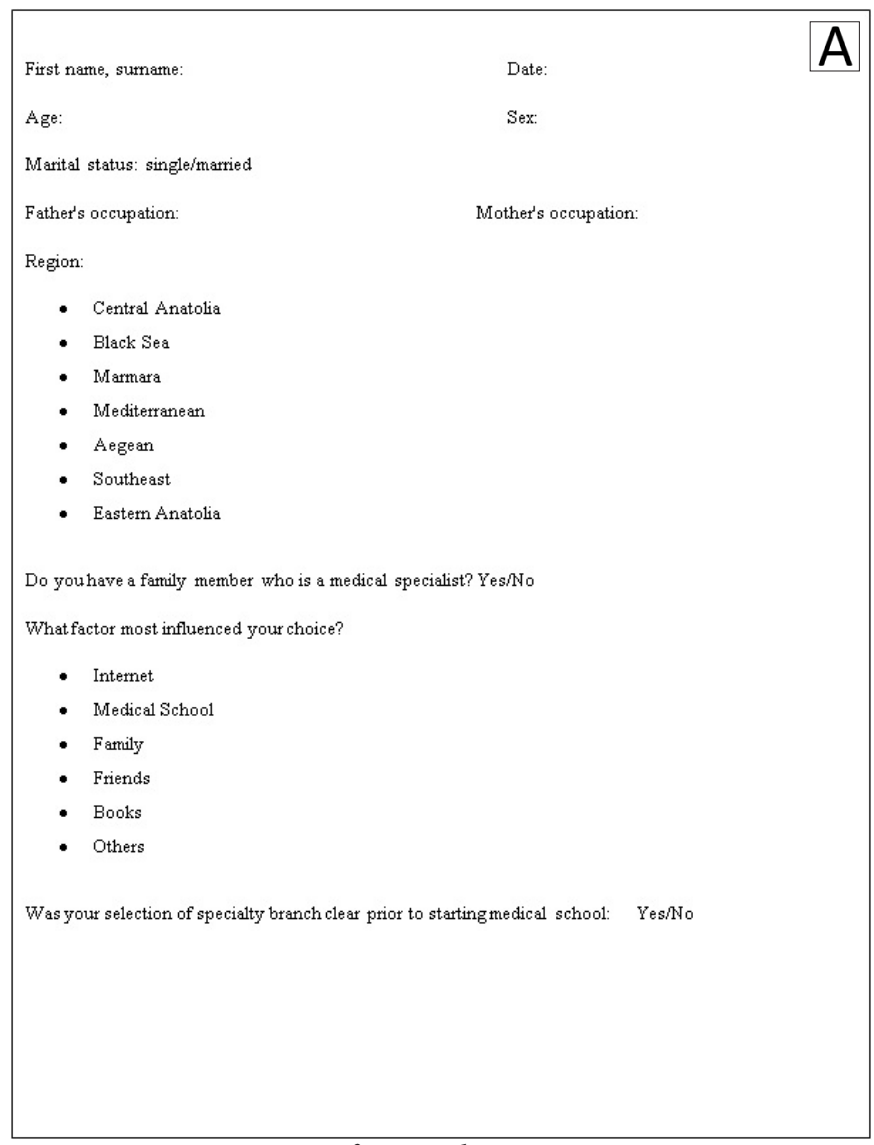

Figure 1a. Questionnaire of career choice 


\begin{tabular}{|c|c|c|c|c|c|}
\hline \multicolumn{5}{|c|}{ Table of preferences } & \multirow{2}{*}{\begin{tabular}{|l}
$\mathbf{B}$ \\
Order
\end{tabular}} \\
\hline Pre-clinical & Order & Non-Surgical & Order & Surgical & \\
\hline Anatomy & & Emergency medicine & & Anesthesiology & \\
\hline $\begin{array}{l}\text { Medical } \\
\text { education and } \\
\text { informatics }\end{array}$ & & $\begin{array}{l}\text { Forensic and legal } \\
\text { medicine }\end{array}$ & & $\begin{array}{l}\text { Plastic reconstructive and } \\
\text { plastic surgery }\end{array}$ & \\
\hline Medical biology & & Pediatric psychiatry & & Pediatric surgery & \\
\hline \begin{tabular}{|l} 
Biophysics \\
\end{tabular} & & Pediatrics & & Neurosurgery & \\
\hline $\begin{array}{l}\text { Medical ethics } \\
\text { and history }\end{array}$ & & Dermatology & & Cardiovascular surgery & \\
\hline Immunology & & Infectious diseases & & Thoracic surgery & \\
\hline \begin{tabular}{|l|} 
Physiology \\
\end{tabular} & & $\begin{array}{l}\text { Chest and pulmonary } \\
\text { medicine }\end{array}$ & & Ophthalmology & \\
\hline $\begin{array}{l}\text { Histology and } \\
\text { embryology }\end{array}$ & & $\begin{array}{l}\text { Physical therapy and } \\
\text { rehabilitation }\end{array}$ & & $\begin{array}{l}\text { Gynecology and } \\
\text { obstetrics }\end{array}$ & \\
\hline \begin{tabular}{|l} 
Microbiology \\
\end{tabular} & & Public health & & $\begin{array}{l}\text { Orthopedics and } \\
\text { traumatology }\end{array}$ & \\
\hline \begin{tabular}{|l} 
Biochemistry \\
\end{tabular} & & Internal medicine & & Pathology & \\
\hline \multirow[t]{6}{*}{ Pharmacology } & & Cardiology & & Urology & \\
\hline & & Neurology & & General surgery & \\
\hline & & Nuclear medicine & & Ear nose and throat & \\
\hline & & Radiation oncology & & & \\
\hline & & Radiology & & & \\
\hline & & Psychiatry & & & \\
\hline
\end{tabular}

Figure 1b. Questionnaire of career choice

questionnaire).

The Statistical Package for the Social Sciences (SPSS for Windows Release 21.0 Standard Version Copyright SPSS, Illinois, USA) program was used for statistical analysis. Descriptive statistics related to categorical variables are shown as numbers and percentages, and those associated with numerical variables are presented as mean, standard deviation, median, minimum, and maximum values. A McNemar test was used to compare categorical variables in dependent groups. Chi-square and Fisher's exact tests were used to compare categorical variables in independent groups. A significance level of 0.05 was set $(p<0.05$ if there was a significant difference; $\mathrm{p}>0.05$ if no significant difference was stated).

\section{RESULTS}

In total, 154 medical students completed the questionnaire before and after their OIP. Most students were from Central Anatolia (71.4\%), where our university is located, and one student was not from Turkey. Most students were single (95.5\%), and only $23(14.9 \%)$ students had other family members who
Table 1. Demographic characteristics of students.

Demographic features $(n=154) \quad$ Number $\quad$ Percentage (\%) Sex

$\begin{array}{lll}\text { Female } & 92 & 59.7 \% \\ \text { Male } & 62 & 40.3 \%\end{array}$

Region

$\begin{array}{lll}\text { Central Anatolia } & 110 & 71.4 \%\end{array}$

$\begin{array}{lll}\text { Black sea } & 12 & 7.8 \%\end{array}$

Mediterranean $\quad 10 \quad 6.5 \%$

$\begin{array}{lll}\text { Marmara } & 9 & 5.85 \%\end{array}$

Eastern Anatolia $\quad 5 \quad 3.25 \%$

Southeastern Anatolia $\quad 4 \quad 2.6 \%$

Aegean $\quad 3 \quad 1.95 \%$

Abroad $110.65 \%$

Marital status

$\begin{array}{lll}\text { Single } & 147 & 95.5 \%\end{array}$

$\begin{array}{lll}\text { Married } & 7 & 4.5 \%\end{array}$

Specialist physician in the family $23 \quad 14.9 \%$

No specialist physician in the family $131 \quad 85.1 \%$

Mother's occupation $^{\star}(\mathrm{n}=154)$

Housewife $\quad 103 \quad 66.9 \%$

$\begin{array}{lll}\text { Teacher } & 20 & 13 \%\end{array}$

$\begin{array}{lll}\text { Nurse } & 13 & 8.45 \%\end{array}$

$\begin{array}{lll}\text { Office worker } & 9 & 5.85 \%\end{array}$

$\begin{array}{lll}\text { Engineer } & 3 & 1.95 \%\end{array}$

Manual worker $\quad 3 \quad 1.95 \%$

$\begin{array}{lll}\text { Retired } & 2 & 1.3 \%\end{array}$

Dental technician $\quad 1 \quad 0.6 \%$

Father's occupation* $(\mathrm{n}=154)$

Public servant $\quad 39 \quad 25.3 \%$

Tradesman $\quad 25 \quad 16.2 \%$

Manual worker $\quad 18 \quad 11.7 \%$

$\begin{array}{lll}\text { Teacher } & 17 & 11.0 \%\end{array}$

$\begin{array}{lll}\text { Soldier } & 11 & 7.2 \%\end{array}$

$\begin{array}{lll}\text { Engineer } & 9 & 5.9 \%\end{array}$

$\begin{array}{lll}\text { Physician } & 7 & 4.6 \%\end{array}$

Laboratory technician $\quad 5 \quad 3.25 \%$

$\begin{array}{lll}\text { Farmer } & 5 & 3.25 \%\end{array}$

$\begin{array}{lll}\text { Academic } & 3 & 1.95 \%\end{array}$

$\begin{array}{lll}\text { Judge } & 3 & 1.95 \%\end{array}$

$\begin{array}{lll}\text { Police officer } & 2 & 1.3 \%\end{array}$

$\begin{array}{lll}\text { Office executive } & 2 & 1.3 \%\end{array}$

Health technician $\quad 2 \quad 1.3 \%$

Imam $\quad 2 \quad 1.3 \%$

$\begin{array}{lll}\text { Building contractor } & 1 & 0.65 \%\end{array}$

$\begin{array}{lll}\text { Manager } & 1 & 0.65 \%\end{array}$

International relations specialist $\quad 1 \quad 0.65 \%$

$\begin{array}{lll}\text { Taxi-driver } & 1 & 0.65 \%\end{array}$

Resources in career choice ${ }^{* *}$

Medical school $\quad 93 \quad 60.4 \%$

$\begin{array}{lll}\text { Friends } & 39 & 25.3 \%\end{array}$

$\begin{array}{lll}\text { Family } & 37 & 24.6 \%\end{array}$

Internet $\quad 29 \quad 18.8 \%$

$\begin{array}{lll}\text { Books } & 9 & 5.8 \%\end{array}$

Other $\quad 28 \quad 18.2 \%$

$\begin{array}{lll}\text { Decided on a specialty prior to } & 28 & 18.2 \%\end{array}$

Decided on a specialty during

medical school

126

$81.8 \%$

${ }^{* *}$ Multiple options were marked 
were specialist medical doctors. Students demographic characteristics are given in Table $\mathbf{1}$.

Our findings showed that after the OIP $83(53.9 \%)$ students had changed their preferences and $72(46.8 \%)$ had changed their order of preference. In total, 22 (14.3\%) students chose orthopedics prior to the internship and 45 (29.2\%) chose orthopedics after the OIP. Prior to the OIP, 4 students (2.6\%) placed orthopedics as their first order of preference. After the OIP, this number increased to $11(7.1 \%)$. The increase in the numbers of students who preferred orthopedics $(\mathrm{p}<0.001)$ and who placed orthopedics as their first order of preference $(\mathrm{p}=0.039)$ was statistically significant after the OIP. Prior to the OIP 100 students placed other surgical specialties in their preference list, while 99 students placed other surgical specialties in their preference list after OIP. Prior to the OIP, 65 students $(42.2 \%)$ marked surgical specialty as their first preference, and this number increased to $67(43.5 \%)$ after the OIP. However, this increase in the number of students marking surgical specialty as their

\begin{tabular}{|c|c|c|c|}
\hline & $\begin{array}{l}\text { Pre-OIP } \\
\mathrm{n}(\%)\end{array}$ & $\begin{array}{l}\text { Post-OIP } \\
\mathrm{n}(\%)\end{array}$ & $\mathrm{p}$ values \\
\hline Who chose orthopedics & $22(14.3 \%)$ & $45(29.2 \%)$ & $<0.001$ \\
\hline $\begin{array}{l}\text { Placed orthopedics in the } \\
\text { first row }\end{array}$ & $4(2.6 \%)$ & $11(7.1 \%)$ & 0.039 \\
\hline $\begin{array}{l}\text { Placed surgical specialties } \\
\text { in the first row }\end{array}$ & $65(42.2 \%)$ & $67(43.5 \%)$ & 0.832 \\
\hline \multicolumn{4}{|l|}{ Marking surgical branches } \\
\hline Female & $39(42.4 \%)$ & $64(69.5 \%)$ & 0.549 \\
\hline Male & $26(41.9 \%)$ & $44(70.9 \%)$ & 0.227 \\
\hline
\end{tabular}

first preference was not statistically significant after the OIP $(p=0.832)$. Details of pre- and post- OIP preferences of students were summarized in Table 2.

Figure 2 shows the distribution of students'pre- and postOIP non-surgical, surgical, and pre-clinical specialization preferences. In terms of female students'first order of preference prior to the OIP, $51(55.4 \%)$ had chosen a non-surgical preference, $39(42.4 \%)$ had selected a surgical preference, and $2(2.2 \%)$ had marked preclinical branches as their first preference; whereas for male students, 35 (56.5\%) had selected non-surgical specialties, 26 (41.9\%) had selected surgical specialties, and $1(1.6 \%)$ had marked pre-clinical branches as their first preference. There was no significant difference between the female and male students in terms of marking surgical branches in their first order of preference pre $(\mathrm{p}=0.955)$ and post OIP $(\mathrm{p}=0.182)$. There was also no significant difference between pre- and post-OIP periods among female $(p=0.549)$ and male $(p=0.227)$ students in terms of marking surgical branches in their first order of preference (Table 3). The prevalence of placing orthopedics in any order on the preference list was statistically higher after the OIP than after the preOIP period in female (3.3-16.3\%) and male (30.6-48.4\%) students $(\mathrm{p}<0.001$ and $\mathrm{p}=0.003$, respectively). However, the increase in placing orthopedics in any order in the preference list was significantly greater in male students than in female students pre- $(\mathrm{p}<0.001)$ and post-OIP $(p<0.001)$. More male students than female students marked orthopedics as their first order of preference both pre- (6.5\%-0\%) and post-OIP (12.9\%-3.3\%) $(\mathrm{p}=0.025$ and $\mathrm{p}=0.029$, respectively). None of the female students and $4(6.5 \%)$ of the male students marked orthopedics in first place pre-OIP, whereas $3(3.3 \%)$ female students and $8(12.9 \%)$ male students marked orthopedics in first place post-OIP (Table 3). However, this increase was not statistically significant $(\mathrm{p}=0.219)$. We found that the order of orthopedics had changed to become the foremost position on 2 female and 3 male students'preference lists in the pre-OIP period. None of the female students removed or downgraded the order of orthopedics in their preference lists. However, post-OIP, 4 male students downgraded the order of orthopedics in their preference list, and 1 student subsequently removed

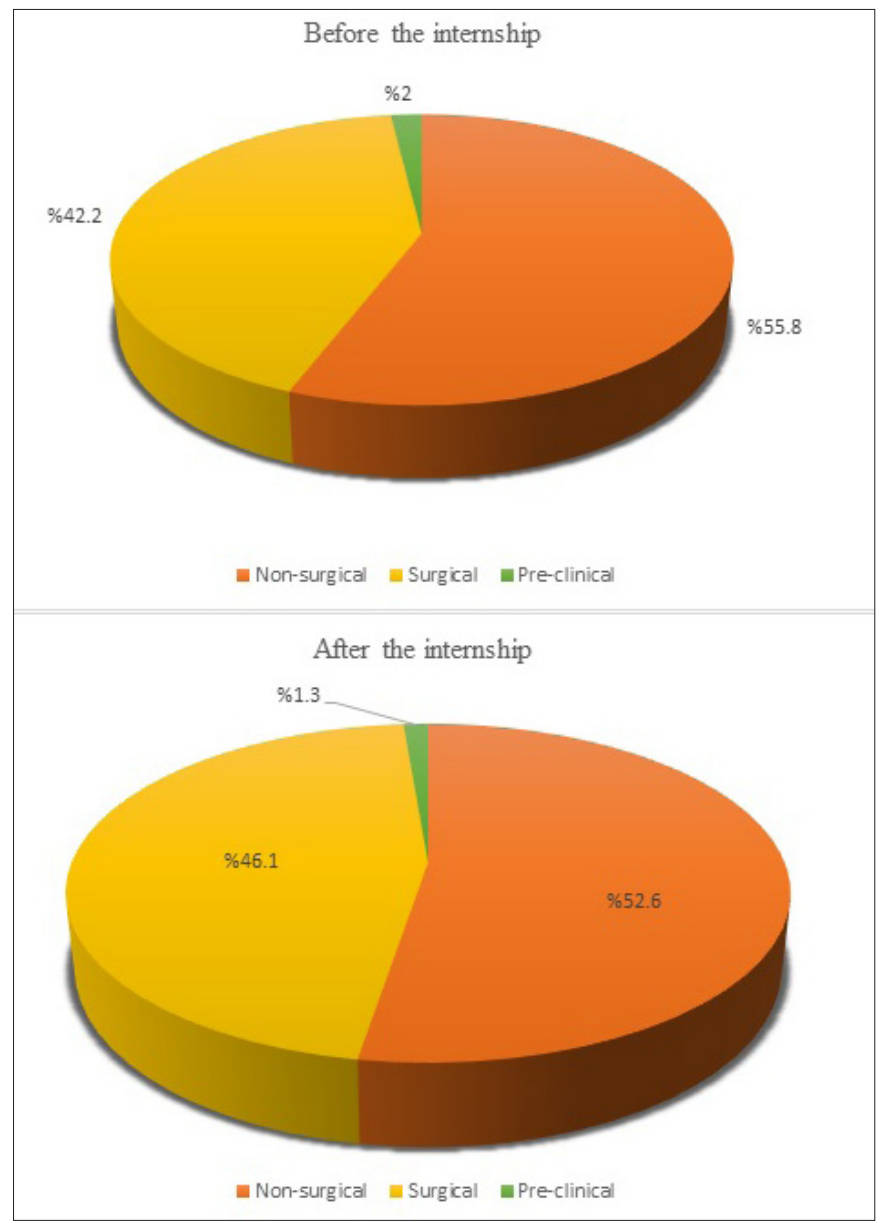

Figure 2. The ratio of students'non-surgical, surgical, and pre-clinical specialization preferences 
Table 3. Details of students' preference by pre- and post-OIP according to gender. (Orthopedic internship program; OIP)

\begin{tabular}{|lcccccc|}
\hline & \multicolumn{2}{c}{ Female n (\%) } & \multicolumn{2}{c|}{ Male n (\%) } & \multicolumn{2}{c|}{ p values } \\
\cline { 2 - 7 } & Pre-OIP & Post-OIP & Pre-OIP & Post-OIP & Pre-OIP & Post-OIP \\
\hline Placed orthopedics in the first row & $0(0 \%)$ & $3(3.3 \%)$ & $4(6.5 \%)$ & $8(12.9 \%)$ & 0.025 & 0.029 \\
Placing orthopedics in any order & $3(3.3 \%)$ & $19(30.6 \%)$ & $15(16.3 \%)$ & $30(48.4 \%)$ & $<0.001$ & $<0.001$ \\
Placed surgical specialties in the first row & $39(42.4 \%)$ & $36(39.1 \%)$ & $26(41.9 \%)$ & $31(50 \%)$ & 0.955 & 0.182 \\
\hline
\end{tabular}

it as a preference. The students who changed the order of orthopedics or removed it from the list stated that orthopedics involved a greater workload and had more complicated operations.

Most students'mothers were housewives (66.9\%) and most students'fathers were public servants (25.3\%). Details of parental occupations are presented in Table 1. Twenty-three $(14.9 \%)$ of the medical students had specialist medical doctors in their families. The distribution of medical students who had a specialist medical doctor in their family was as follows; 6 family medicine, 3 pediatrics, 2 internal medicine, 2 orthopedics, 2 ophthalmology, 2 emergency medicine, 1 physical therapy and rehabilitation, 1 nuclear medicine, 1 public health, 1 pathology, 1 microbiology, 1 psychiatry, 1 general surgery, 1 pediatric surgery, 1 ear nose and throat, and 1 anesthesiology. Of these, 13 students indicated that family-derived information determined their career choice. Two (8.6\%) students with specialist doctors in their families chose orthopedics pre-OIP and $6(26 \%)$ students chose orthopedics post-OIP, whereas $20(15.3 \%)$ of the other students chose orthopedics pre-OIP and 39 (29.8\%) chose orthopedics post-OIP. Of the medical students who had specialist doctors in their families, 7 (30.4\%) marked orthopedics first on their list of preferences pre-OIP and 8 (34.8\%) marked orthopedics first on their preference list post-OIP. The frequency of choosing orthopedics as a specialty was significantly higher post-OIP among students with parents in non-medical occupations $(\mathrm{p}<0.001)$.

Ninety-three $(60.4 \%)$ students stated that the medical school had influenced their career choice, and most students $(81.8 \%)$ stated that they had made decisions concerning their career while at medical school. Details of possible factors influencing career choice and decision-making for specialty selection are shown in Table 1.

There were 7 (4.5\%) married students (3 women, 4 men), none of whom chose orthopedics pre-OIP, whereas one married female and one married male student added orthopedics to their preference list postOIP. The remaining 6 married students prioritized nonsurgical specialties both pre- and post-OIP.

\section{DISCUSSION}

This is the first study to determine factors affecting the selection of a medical specialty and choice distribution among 5th-year medical students in Turkey. This pioneering study investigated the factors that affected the specialty choice of medical students and if their preferences changed after the OIP. One of the main study findings was that there were changes in student preferences and preference order after the OIP. However, the number of students who chose surgical specialties did not differ significantly after the OIP. Students undertaking the OIP usually spend their time actively in the outpatient clinic, in patient rooms, in the operating room (OR), and in the orthopedics training laboratory which may explain the increase in the students'choice of orthopedics in their preferences in the early post-OIP period. Therefore, these changes may be temporary, with further changes occurring due to other internship programs. It is possible that the practical aspects of orthopedics, such as casting and splinting, and using plates, screws and hammers might attract certain students more readily than to other surgical branches. On the other hand, this increase in the choice of orthopedics could be a result of the change in the students'perspective regarding surgical branches which may help overcome their reluctance to pick surgical specialties.

A decrease in the selection of surgical specialties among medical students remains a current issue for healthcare services and medical education facilities internationally (18-21). Williams et al. (21) estimated that there would be a deficit of orthopedic surgeons in the United States of America in 2030. Turkey faces a similar situation, where compared with the number of students preferring surgical programs, the number of students preferring both pre-clinical and non-surgical residency programs has increased each year. To address a potential lack of surgeons in the near future, factors affecting career choices in medical education need to be determined.

More than half the students (60.4\%) reported their medical school experience and education as the most influential factors in their decision-making. However, there was no significant change in the number of students who chose surgical branches after the 3-week OIP. In contrast, Marshall et al. (22) reported an increased 
interest in a surgical career and positive experiences gained within the surgical rotation. Many factors related to career decision-making have been reported to play a significant role in positive experiences. Sedaghat et al. (23) reported that intensive exposure to surgical practice assisted the early student classes with future planning. Cloyd et al. (24) underlined the importance of strong mentorship from the surgical faculty in attracting interest in surgical careers. Active involvement in the OR with exposure to role models (25-27) and supportive relationships with both faculty members and OR staff (27) have been reported to result in positive experiences for medical students, which may influence their choice of a surgical career. In our study, the significant increase in the number of students who added orthopedics to their list of preferences post-OIP may have been related to positive experiences gained during the 3-week OIP. However, there was no increase in preferences for other surgical branches post-OIP. The unchanged status of choosing surgical specialties rather than orthopedics post-OIP may have been due to differences between the OIP content and that of other surgical education programs. The students may have been more actively involved in the OIP with more positive experiences consequently. Moreover, if completion of a program is accepted as a factor affecting career choice in medicine, attendance or nonattendance at other surgical branches at the time of OIP may also have played a role in this result. Wijnen et al. (28) underlined that scientific and empirical-based working methods, knowing their personal limits and possibilities, active professional development, teamwork, and verbal communication with colleagues and supervisors are the most important competences for entrustment decisions of supervisors. The OIP provided certain benefits for the medical students, such as direct and active instructional contact with the orthopedic faculty, find out their personal limits, learning how to be a part of teamwork, including sharing any information about the content, and frankly discussing the positives and negatives of live as an orthopedics resident and life post-residency.

The students'sex may have been a determinant in specialty preference (29). Orthopedic surgery has been reported to be one of the least preferred subspecialties of surgery among female students, (30) despite reports indicating that the total number of female medical students undertaking OIPs has increased (20,30). Our study showed a significant difference between male and female students in selecting orthopedics both pre-OIP (30.6\% vs. $3.3 \%$, respectively) and post-OIP (48.4\% vs. $16.3 \%$, respectively), although the rates of selecting a surgical specialty were similar. The rates of selecting surgery among female students were similar to those reported in other studies $(2,32)$. Chew et al. (33) stated that female medical students in Malaysia were 1.91 times more likely to choose internal medicine than their male counterparts. In terms of orthopedic surgery, the results in relation to male and female preferences appear more concerning as only $16.3 \%$ of female students reported an interest in orthopedic surgery, whereas only 3 students (3.3\%) reported placing orthopedics first in their list of preferences post-OIP, and these results are similar to other studies concerning orthopedic residency programs and interest among female students $(16,19,31,33)$. Despite an increase in the number of female medical school students, lower reported rates of interest in surgery and an even lower interest in orthopedics are likely to provide challenges in recruiting high-achieving students into these specialties (31). Failure to attract female students to orthopedics has been reported to be related to factors such as a lack of role models, a perception of physical inadequacy, a mismatch of family life, and the difficulties of orthopedic residency $(34,35)$.

The availability of a non-surgical specialty concerning physical medicine and rehabilitation in treating musculoskeletal system diseases may be another factor contributing to the lack of female orthopedic surgeons. Lambert et al. (36) stated that, popularity of specialties offering a better work/life balance among female students had led to increase in the number of women medical students and to more interest in non-scientific fields than in medicine when compared with previous generations. However, we consider that the reported male dominance in surgery in previous studies cannot simply be associated with the demanding mechanical and technical aspects of the profession as female medical students have been found to be as proficient in terms of surgical and mechanical skills as their male counterparts $(35,37)$. In support of this view, we found that none of the female students removed or downgraded the ranking of orthopedics among their preferences. Baldwin et al. (20) in their retrospective study of factors affecting the interest of female medical students in orthopedics, reported that long working hours, length of residency, and the nature and physical demands of orthopedic procedures were major factors that led to a decreased interest in orthopedics. To increase female students'interest in orthopedics, early exposure to orthopedic education and more practical experience may be effective. Blackmore et al. (31) suggested the creation and implementation of maternity support policies in training programs and in practice to boost female interest in orthopedic surgery.

Of 23 students who had specialist doctors in their family, only 2 students had chosen the same specialization as the family member prior to the OIP, and one student had completely removed orthopedics from their preference list. The remaining 20 students did not choose the same specialization as their family. Baldwin et al. (20) reported 
that medical students who had orthopedic surgeons as close friends or family members did not show any significant preference for selecting orthopedic surgery. Similarly, this study found that 2 students who had orthopedic surgeons in their families as well as other students who had specialist doctors in their families did not choose the same specialization as the specialist in their families, although they referred to their family as the most influential factor in their career choice. This finding may be because new-generation medical students tend to be influenced in their career selection primarily role models during their OIP. Johnson et al. (38) found that among 4th-year medical students, the most influential individuals were faculty and resident staff, in terms of affecting residency choice. Blackmore et al. (31) suggested that better representation of orthopedics by both faculty and residents may help students to select orthopedics as a surgical specialty.

This study had several limitations. The questionnaire was conducted pre- and post-OIP. If it had been conducted at the beginning and at the end of the 5th-year of medical school, the final-year students might have provided more informed responses, with more information available concerning all the specialty branches. Changes to specialist preferences may be temporary and student responses may have been affected due to recent exposure to orthopedics. Moreover, each class had completed different internships prior to starting OIP. Therefore, the preferences of students who complete different internships are likely to differ accordingly. In a future study, it is necessary to question the students who have completed 6th year to assess whether the students'interest in surgical branches still continue. Factors such as negative work/life balance, enforced residency, and higher income may have affected students' career choices and these factors were not examined in the study. The questionnaire was not pilot-tested, could have been tested to increase its reliability. Finally, a multicenter study with a greater number of participants, would allow further and more thorough investigation of this topic for gathering both country based, and worldwide data and such a study is recommended in future.

\section{CONCLUSIONS}

Non-surgical residency programs are chosen more often than surgical programs in the career choices of medical students, which is likely to lead to a deficit in the number of surgeons in Turkey and countries with similar education programs. Interest in orthopedics among female students is extremely low, mainly due to the lack of role models, the physical demands of the surgical procedures, and a negative work/life balance. A combination of various factors may affect career choice before, during, and after each internship. We demonstrated that early and active recruitment in orthopedics (outpatient clinic and patients'room) and the OR with positive support from faculty, residents, and OR staff may increase interest in orthopedic surgery for both male and female medical students. Therefore, we suggest planning the surgical internship programs by active recruitment of medical students to increase interest in surgical branches.

\section{ETHICAL DECLARATIONS}

Ethics Committee Approval: The study was approved by the local Ethics Committee (Date: 11.07.2018, Approval no. 2018.10.16) and performed in the skill practice laboratory of the Department of Orthopedics and Traumatology at Kirıkkale University School of Medicine.

Informed Consent: All patients signed the free and informed consent form.

Referee Evaluation Process: Externally peer-reviewed.

Conflict of Interest Statement: The authors have no conflicts of interest to declare.

Financial Disclosure: The authors declared that this study has received no financial support.

Author Contributions: All of the authors declare that they have all participated in the design, execution, and analysis of the paper, and that they have approved the final version.

\section{REFERENCES}

1. Hauer KE, Durning SJ, Kernan WN, et al. Factors associated with medical students' career choices regarding internal medicine. JAMA 2008; 300: 1154-64.

2. Lefevre JH, Roupret M, Kerneis S, et al. Career choices of medical students: a national survey of 1780 students. Med Educ 2010; 44: 603-12.

3. Wigney T and Parker G. Factors encouraging medical students to a career in psychiatry: qualitative analysis. Aust N Z J Psychiatry 2008; 42: 520-5.

4. Takeda Y, Morio K, Snell L, et al. Characteristic profiles among students and junior doctors with specific career preferences. BMC Med Educ 2013; 13: 125.

5. Newton DA, Grayson MS and Thompson LF. The variable influence of lifestyle and income on medical students' career specialty choices: data from two U.S. medical schools, 1998-2004. Acad Med 2005; 80: 809-14.

6. Gorenflo DW, Ruffin MTt and Sheets KJ. A multivariate model for specialty preference by medical students. J Fam Pract 1994; 39: 570-6.

7. Harris MG, Gavel PH and Young JR. Factors influencing the choice of specialty of Australian medical graduates. Med J Aust 2005; 183: 295-300.

8. Cleland JA, Johnston PW, Anthony M, et al. A survey of factors influencing career preference in new-entrant and exiting medical students from four UK medical schools. BMC Med Educ 2014; 14: 151 .

9. Schwartz RW, Jarecky RK, Strodel WE, et al. Controllable 
lifestyle: a new factor in career choice by medical students. Acad Med 1989; 64: 606-9.

10.Dorsey ER, Jarjoura D and Rutecki GW. Influence of controllable lifestyle on recent trends in specialty choice by US medical students. JAMA 2003; 290: 1173-8.

11.Saigal P, Takemura Y, Nishiue T, et al. Factors considered by medical students when formulating their specialty preferences in Japan: findings from a qualitative study. BMC Med Educ 2007; 7: 31

12. Cleland J, Johnston PW, French FH, et al. Associations between medical school and career preferences in Year 1 medical students in Scotland. Med Educ 2012; 46: 473-84.

13. Rosenblatt RA, Cherkin DC, Schneeweiss R, et al. The structure and content of family practice: current status and future trends. J Fam Pract 1982; 15: 681-722.

14. Craton N and Matheson GO. Training and clinical competency in musculoskeletal medicine. Identifying the problem. Sports Med 1993; 15: 328-37.

15. Rekola KE, Keinanen-Kiukaanniemi S and Takala J. Use of primary health services in sparsely populated country districts by patients with musculoskeletal symptoms: consultations with a physician. J Epidemiol Community Health 1993; 47: 153-7.

16.Schroeder JE, Zisk-Rony RY, Liebergall M, et al. Medical students'and interns'interest in orthopedic surgery: the gender factor. J Surg Educ 2014; 71: 198-204.

17. Weissman C, Schroeder J, Elchalal U, et al. Using marketing research concepts to investigate specialty selection by medical students. Med Educ 2012; 46: 974-82.

18.Bath MF, Harries RL and Gokani VJ. Medical Students'and Interns'Interest in Orthopedic Surgery: The Gender Factor. J Surg Educ 2017; 74: 1.

19. Correia Lima de Souza L, Mendonca VR, Garcia GB, et al. Medical Specialty Choice and Related Factors of Brazilian Medical Students and Recent Doctors. PLoS One 2015; 10 0133585.

20.Baldwin K, Namdari S, Bowers A, et al. Factors affecting interest in orthopedics among female medical students: a prospective analysis. Orthopedics 2011; 34: 919-32.

21.Williams TE, Jr., Satiani B, Thomas A, et al. The impending shortage and the estimated cost of training the future surgical workforce. Ann Surg 2009; 250: 590-7.

22.Marshall DC, Salciccioli JD, Walton SJ, et al. Medical student experience in surgery influences their career choices: a systematic review of the literature. J Surg Educ 2015; 72: 438-45.

23. Sedaghat N, Mondy J, Eslick GD, et al. Exposure of medical students to surgery: the Nepean summer vacation surgical program. J Surg Educ 2012; 69: 580-7.

24.Cloyd J, Holtzman D, O'Sullivan P, et al. Operating room assist: surgical mentorship and operating room experience for preclerkship medical students. J Surg Educ 2008; 65: 275-82.

25.Berman L, Rosenthal MS, Curry LA, et al. Attracting surgical clerks to surgical careers: role models, mentoring, and engagement in the operating room. J Am Coll Surg 2008; 207: 793-800.

26. Redlich PN, Milkowski T, Bragg D, et al. Multiple variables influence the educational value of surgical clerkship sites. Am J Surg 2006; 191: 178-82.

27. Fernando N, McAdam T, Youngson G, et al. Undergraduate medical students'perceptions and expectations of theatre-based learning: how can we improve the student learning experience? Surgeon 2007; 5: 271-4.

28.Wijnen-Meijer M, van der Schaaf M, Nillesen K, et al. Essential facets of competence that enable trust in medical graduates: a ranking study among physician educators in two countries. Perspect Med Educ 2013; 2: 290-7.
29. Anand, R. and P.S. Sankaran, Factors influencing the career preferences of medical students and interns: a cross-sectional, questionnaire-based survey from India. J Educ Eval Health Prof, 2019. 16: 12 .

30. Brotherton SE, Rockey PH and Etzel SI. US graduate medical education, 2003-2004. JAMA 2004; 292: 1032-7.

31. Blakemore LC, Hall JM and Biermann JS. Women in surgical residency training programs. J Bone Joint Surg Am 2003; 85: 2477-80.

32. Boyle E, Healy D, Hill AD, et al. Career choices of today's medical students: where does surgery rank? Ir J Med Sci 2013; 182: 337-43.

33. Chew YW, Rajakrishnan S, Low CA, et al. Medical students'choice of specialty and factors determining their choice: a cross-sectional questionnaire survey in Melaka-Manipal Medical College, Malaysia. Biosci Trends 2011; 5: 69-76.

34.Bernstein J, Dicaprio MR and Mehta S. The relationship between required medical school instruction in musculoskeletal medicine and application rates to orthopaedic surgery residency programs. J Bone Joint Surg Am 2004; 86: 2335-8.

35.Egol KA, Collins J and Zuckerman JD. Success in orthopaedic training: resident selection and predictors of quality performance. J Am Acad Orthop Surg 2011; 19: 72-80.

36.Lambert EM and Holmboe ES. The relationship between specialty choice and gender of U.S. medical students, 1990-2003. Acad Med 2005; 80: 797-802.

37.Pico K, Gioe TJ, Vanheest A, et al. Do men outperform women during orthopaedic residency training? Clin Orthop Relat Res 2010; 468: 1804-8.

38. Johnson AL, Sharma J, Chinchilli VM, et al. Why do medical students choose orthopaedics as a career? J Bone Joint Surg Am 2012; 94: 78 . 